\title{
PENGARUH PERSEPSI PESERTA DIDIK DALAM PENGELOMPOKAN KELAS TERHADAP HASIL BELAJAR DAN ETIKA PERGAULAN
}

\author{
Alisa Widiya Lestari dan Sulasfiana Alfi Raida \\ Institut Agama Islam Negeri Kudus \\ E-mail: alisawidiya9@gmail.com; sulasfiana@iainkudus.ac.id
}

\section{Info Artikel}

Sejarah Artikel:

Diserahkan 15 April 2020

Direvisi 23 Juni 2020

Disetujui 23 Juni 2020

Keywords:

classification perception,

learning outcomes,

social ethics

\begin{abstract}
This research to obtain information and analyze data about the effect of students 'perceptions in class grouping on learning outcomes and the students' social ethics in the subject of the moral code of class VIII MTs Ma'ahid Kudus.

This research uses a quantitative approach, which was carried out at MTs Ma'ahid Kudus Jl. K.H. Muhammad Arwani, Bakalan Krapyak Kaliwungu District, Kudus Regency. The population in studens of class VIII taken as many as 135 students by using purposive sampling technique.

The results of the study show that: (1) The learning outcomes of the moral subjects of the VIII MTs Ma'ahid Kudus are included in the good category, which is at intervals (94-89). (2) The social ethics of students in class VIII MTs Ma'ahid Kudus is included in the good category, namely at intervals (50-54). (3) The influence between students 'perceptions in class grouping on students' cognitive learning outcomes in the moral subjects of the VIII grade at MTs Ma'ahid Kudus is 32\%. (4) The influence between students 'perceptions in class grouping on the students' social ethics in the VIII moral subjects in MTs Ma'ahid Kudus is $37 \%$.
\end{abstract}

\begin{abstract}
Abstrak
Penelitian ini bertujuan untuk mendapatkan informasi dan menganalisis data tentang pengaruh persepsi peserta didik dalam pengelompokan kelas terhadap hasil belajar dan etika pergaulan peserta didik pada mata pelajaran Akidah Akhlak kelas VIII MTs Ma'ahid Kudus.

Penelitian ini menggunakan pendekatan kuantitatif, yang dilaksanakan di MTs Ma'ahid Kudus Jl. K.H. Muhammad Arwani, Bakalan Krapyak Kecamatan Kaliwungu Kabupaten Kudus. Populasi pada penelitian ini yaitu siswa kelas VIII yang diambil sampel sebanyak 135 peserta didik dengan menggunakan teknik purposive sampling.

Hasil penelitian menunjukkan bahwa: (1) Hasil belajar mata pelajaran akidah akhlak kelas VIII MTs Ma'ahid Kudus termasuk kategori baik, yaitu berada pada interval (94-89). (2) Etika pergaulan peserta didik kelas VIII MTs Ma'ahid Kudus termasuk pada kategori baik, yaitu pada interval (50-54). (3) Pengaruh antara persepsi peserta didik dalam pengelompokan kelas terhadap hasil belajar kognitif peserta didik pada mata pelajaran akidah akhlak kelas VIII di MTs Ma'ahid Kudus sebesar $32 \%$. (4) Pengaruh antara persepsi peserta didik dalam pengelompokan kelas terhadap etika pergaulan peserta didik pada mata pelajaran akidah akhlak kelas VIII di MTs Ma'ahid Kudus sebesar $37 \%$.
\end{abstract}




\section{PENDAHULUAN}

Pendidikan merupakan proses pengembangan kemampuan, sikap, dan tingkah laku peserta didik di dalam lingkungan hidupnya. Dengan pendidikan diharapkan peserta didik memiliki akhlak yang mulia, kepribadian yang baik, kecerdasan intelektual, serta keterampilan yang diperlukan dalam lingkungan masyarakat (Hamdani, 2011).

Pendidikan diharapkan mampu mengarahkan perilaku dan sikap peserta didik agar sesuai dengan nilai dan norma yang berlaku di masyarakat. Dalam hal ini maka pendidikan agama Islam memiliki peran penting, sebab semua sisi kehidupan manusia telah diatur ketentuannya langsung dari Tuhan Yang Maha Esa, bukan ciptaan manusia. Bagi umat Islam, agama adalah dasar atau pondasi dalam melaksanakan pendidikan, karena ajaran agama Islam mengandung aturan-aturan yang mengatur seluruh aspek kehidupan manusia, baik dalam hal hubungan manusia dengan Tuhannya maupun hubungan manusia dengan sesamanya.

Dewasa ini makin terasa nilai-nilai agama, adat dan norma, mulai diabaikan oleh sebagian masyarakat. Banyak permasalahan yang dihadapi peserta didik akibat dari pergaulannya di kehidupan sehari-hari yang memprihatinkan. Sebagaimana banyak terjadi kasus yang melibatkan peserta didik antara lain perkelahian antar pelajar, masalah narkoba maupun pergaulan bebas.

Harianto (2018) mencatat angka kenakalan remaja yang dilakukan oleh peserta didik di wilayah Kabupaten Nganjuk meningkat selama tahun 2018 dibandingkan dengan tahun 2017. Data dari unit Pelayanan Perempuan dan Anak (PPA) Kapolres Nganjuk menyebutkan bahwa pada tahun 2018 tercatat 55 kasus kenakalan remaja dan tahun 2017 hanya 36 kasus, atau naik 50\% dari tahun sebelumnya. 55 kasus tersebut terdiri dari 8 kasus penganiayaan, 5 kasus pengkeroyokan, 13 kasus pencurian, 18 kasus persetubuhan dan 1 kasus perjudian

Pendidikan Islam diharapkan dapat mengatasi fenomena-fenomena diatas. Pendidikan Islam sebagai proses pembentukan individu yang berdasarkan pada nilai-nilai Islam sehingga dapat diamalkan di kehidupan sehari-hari dan memetik hasilnya di akhirat kelak (Azra, 2014). Hal tersebut sejalan dengan pendapat Ningrum (2015) bahwa tujuan pendidikan Islam yaitu terwujudnya kepribadian individu yang sesuai dengan ajaran Islam bertaqwa kepada Tuhan serta berbuat baik kepada sesama.

Upaya pencapaian tujuan pendidikan Islam, dapat dilakukan melalui kegiatan pembelajaran secara efektif di sekolah. Pembelajaran yang efektif dapat dilihat dari dua aspek, yaitu aspek guru dan aspek murid. Pertama, aspek guru, yaitu pelaksanaan kegiatan belajar mengajar yang telah direncanakan oleh guru. Pembelajaran pasti memiliki perencanaan yang matang, semakin banyak perencanaan yang matang, semakin banyak perencanaan yang dapat terlaksana, maka pembelajaran tersebut dapat dikategorikan efektif. Kedua, aspek peserta didik, yaitu pembelajaran dikatakan efektif apabila peserta didik memiliki kemampuan untuk menyerap atau memahami materi yang disampaikan guru (Muchith, 2008). Lebih lanjut Yusuf (2017) menyatakan bahwa pembelajaran yang efektif mampu menciptakan suasana pembelajaran yang komunikatif dan aktif serta respon yang positif dari peserta didik.

Guru memiliki peran yang penting dalam kegiatan pembelajaran. Peran guru dalam pembelajaran adalah multi peran atau bervariasi sesuai dengan situasi yang ada. Muchith (2008) menyebut peran guru antara lain guru harus mampu menjelma sebagai seorang ayah yang penuh tanggung jawab dalam menyelesaikan segala urusan, menjelma sebagai seorang ibu yang memiliki sifat sabar dan penuh kasih sayang serta berusaha membimbing, mengoreksi atau membenahi kesalahan yang terjadi, sebagai tentara yang memiliki ketegasan dan kedisiplinan yang tinggi dalam menjalankan aktivitas dan dalam menghadapi setiap permasalahan.

Guru juga harus mampu menciptakan kondisi dan suasana kelas yang menyenangkan. Kondisi kelas memberikan pengaruh yang besar terhadap proses dan hasil belajar peserta didik. Guru harus mampu mengatur ruangan kelas agar dapat menunjang perkembangan peserta didik secara optimal (Karwati, 2015). Hal tersebut dapat diwujudkan melalui pengelolaan kelas yang menyangkut peserta didik maupun pengelolaan fasilitas berupa situasi fisik yaitu ruangan dan alat yang digunakan untuk mendukung kegiatan pembelajaran di lingkungan kelas (Kompri, 2014).

Salah satu cara pengelolaan kelas yang menyangkut peserta didik yaitu dengan menerapkan pemisahan antara kelas laki-laki dan kelas perempuan, sehingga diharapkan peserta didik dapat fokus berkonsentrasi 
dalam kegiatan pembelajaran. Ketika kelas dicampur dengan laki-laki dan perempuan, umumnya peserta didik merasa canggung ataupun malu ketika berada dalam satu kelas dengan peserta didik yang berlainan jenis kelamin, sehingga berpengaruh pada hasil belajarnya. Pengelompokan kelas berdasarkan jenis kelamin menjadi alternatif yang dapat diterapkan.

Seorang peneliti dari Universitas Cambridge, UK, menemukan bahwa kelas yang terpisah mampu meningkatkan hasil belajar peserta didik serta memudahkan peserta didik berkonsentrasi dalam kegiatan pembelajaran. Peneliti dari Universitas Steton di Florida, Amerika Serikat, membandingkan hasil belajar di kelas terpisah dan kelas campuran melalui tes FCAT (Florida Comprehensive Assessment Test) dengan hasil sebagai berikut.

Tabel 1. Perbandingan Hasil Belajar antara Kelas Campuran dan Kelas Terpisah

\begin{tabular}{|l|c|c|}
\hline \multicolumn{1}{|c|}{ Kategori } & $\begin{array}{c}\text { Peserta didik } \\
\text { laki-laki }\end{array}$ & $\begin{array}{c}\text { Peserta didik } \\
\text { perempuan }\end{array}$ \\
\hline $\begin{array}{l}\text { Kelas } \\
\text { campur }\end{array}$ & $37 \%$ berhasil & $59 \%$ berhasil \\
\hline $\begin{array}{l}\text { Kelas } \\
\text { terpisah }\end{array}$ & $86 \%$ berhasil & $75 \%$ berhasil \\
\hline
\end{tabular}

Berdasarkan hasil penelitian di atas dapat disimpulkan bahwa dengan menerapkan kelas yang terpisah dapat memberikan kesempatan pada peserta didik untuk mengeksplorasi diri secara maksimal serta dapat meningkatkan rasa percaya diri untuk menguasai mata pelajaran. Berdasarkan hal tersebut, keadaan kelas dengan interaksi yang baik antar penghuni kelas, akan mempengaruhi keaktifan peserta didik dalam kelas sehingga hasil belajarnya pun akan meningkat (Pawitasari, 2015).

Pengelompokan kelas berdasarkan jenis kelamin memunculkan persepsi bagi peserta didik. Setiap peserta didik memiliki persepsi yang berbeda-beda dalam menanggapi lingkungannya. Arifin (2018) menyatakan bahwa peserta didik yang memiliki persepsi yang positif akan menimbulkan aktivitas belajar yang baik sehingga menghasilkan hasil belajar yang baik pula.

Madrasah Tsanawiyah Ma'ahid Kudus merupakan sekolah yang menerapkan pengelompokan kelas berdasarkan jenis kelamin. Tidak hanya kelas, lokasi madrasah pun terpisah antara laki-laki dan perempuan. Hal tersebut diterapkan karena sekolah ini berbasis pondok pesantren sehingga antara laki-laki dan perempuan harus terpisah. Hasil wawancara peneliti dengan kepala MTs Ma'ahid menyatakan bahwa pengelompokan peserta didik tersebut dilaksanakan dengan tujuan agar peserta didik lebih fokus dalam mengikuti pembelajaran serta untuk menjaga pergaulan antara peserta didik laki-laki dan perempuan terlebih saat memasuki masa remaja.

Masa remaja merupakan masa peralihan dari anak-anak menuju dewasa sebagai tahap perkembangan seseorang yang membutuhkan pembinaan demi masa depan yang lebih baik. Dibutuhkan madrasah yang serius dan mampu membimbing sikap atau etika peserta didik yang sesuai dengan ajaran Islam, termasuk etika dalam pergaulan antara laki-laki dan perempuan dalam kehidupan sehari-hari.

Islam telah mengatur batasan-batasan dalam pergaulan, sehingga perilaku tersebut perlu diperhatikan dan dibiasakan dalam kehidupan sehari-hari. Etika pergaulan yang sesuai dengan ajaran Islam sangat penting bagi peserta didik, karena dengan adanya etika maka akan terbentuk akhlaqul karimah di dalam diri peserta didik (Ahmad, 2016).

Pembelajaran di madrasah yang membahas tentang etika dan sikap peserta didik terdapat dalam mata pelajaran akidah akhlak. Disampaikannya mata pelajaran ini diharapkan agar peserta didik mampu mengenal dan memahami keyakinannya kepada Allah SWT sehingga dapat direalisasikan dalam bentuk sikap yang sesuai dengan ajaran agama Islam. Pembelajaran ini penting disampaikan kepada peserta didik sebagai pedoman dalam bersikap dan beretika dalam kehidupan sehari-hari.

Salah satu materi pada mata pelajaran akidah akhlak yang penting disampaikan kepada peserta didik yaitu materi akhlak tercela. Materi tersebut membahas mengenai perilaku-perilaku yang wajib di hindari dalam berinteraksi dan bergaul di kehidupan seharihari di lingkungan sekolah, keluarga, maupun masyarakat. Akhlak tercela wajib dihindari karena dapat menimbulkan berbagai macam kerugian, bagi diri sendiri, orang lain, maupun lingkungan sekitar. Apabila peserta didik memiliki pengetahuan mengenai hal-hal yang berkaitan dengan akhlak tercela, maka dari pengetahuan tersebut dapat dijadikan pedoman peserta didik dalam beretika dan bergaul di kehidupan sehari-hari. 
Berdasarkan latar belakang diatas maka penelitian ini bertujuan untuk 1) menjelaskan hasil belajar kognitif peserta didik pada mata pelajaran akidah akhlak kelas VIII di MTs Ma'ahid Kudus. 2) menjelaskan hasil belajar afektif (etika pergaulan) peserta didik pada mata pelajaran akidah akhlak kelas VIII di MTs Ma'ahid Kudus. 3) menjelaskan seberapa besar pengaruhpersepsi peserta didik dalampengelompokan terhadap hasil belajar kognitif peserta didik pada mata pelajaran akidah akhlak kelas VIII di MTs Ma'ahid Kudus. 4) menjelaskan seberapa besar pengaruh persepsi peserta didik dalampengelompokan kelas terhadap hasil belajar afektif (etika pergaulan) peserta didik pada mata pelajaran akidah akhlak kelas VIII di MTs Ma'ahid Kudus.

\section{METODE PENELITIAN}

Penelitian ini menggunakan jenis penelitian lapangan (field research), dengan pendekatan kuantitatif.Variabel bebas pada penelitian ini adalah persepsi pengelompokan kelas berdasarkan jenis kelamin (X). Variabel terikat pada penlitian ini adalah hasil belajar $\left(\mathrm{Y}_{1}\right)$ dan etika pergaulan $\left(\mathrm{Y}_{2}\right)$

Penelitian ini dilaksanakan di MTs Ma'ahid Kudus J1. K.H. Muhammad Arwani, Bakalan Krapyak Kecamatan Kaliwungu Kabupaten Kudus. Lokasi tersebut dipilih atas pertimbangan madrasah tersebut menerapkan sistem pengelompokan kelas berdasarkan jenis kelamin.

Populasi dalam penelitian ini adalah seluruh peserta didik kelas VIII di MTs Ma'ahid Kudus tahun pelajaran 2018/2019 yang berjumlah 134 peserta didik yang terdiri dari 5 kelas. Sampel pada penelitian ini adalah kelas VIII C, D dan B, E dengan pertimbangan kelas tersebut mewakili dari jenis kelamin, yaitu kelas B dan E merupakan kelas perempuan dan kelas $\mathrm{C}$ dan $\mathrm{D}$ adalah kelas laki-laki, serta kelas tersebut diampu oleh guru yang sama pada mata pelajaran akidah akhlak sehingga peserta didik mendapatkan perlakuan yang sama dalam kegiatan pembelajaran. Pengambilan sampel dilakukan dengan teknik purposive sampling.

Instrumen yang digunakan yaitu instrumen tes dan angket. Instrumen tes digunakan untuk mendapatkan data terkait hasil belajar peserta didik. Angket digunakan untuk memperoleh data tentang persepsi peserta didik dan etika pergaulan peserta didik. Setelah data telah diperoleh, maka dilakukan syarat uji yaitu uji normalitas dan uji linieritas.
Uji normalitas digunakan untuk mengetahui apakah kondisi data berdistribusi normal atau tidak normal. Adapun teknik yang digunakan untuk uji normalitas data dalam penelitian ini adalah dengan menggunakan uji normalitas Kolmogorov Smirnov dengan taraf signifikansi sebesar 0,05. Melalui bantuan progam SPSS 16 diperoleh nilai signifikansi sebesar 0,499 atau lebih dari 0,05. Sehingga dapat disimpulkan bahwa data berdistribusi normal.

Uji linieritas digunakan untuk mengetahui garis regresi antara $\mathrm{X}$ dan $\mathrm{Y}$ membentuk garis linier atau tidak.Pengujian linieritas data dapat dilakukan dengan cara menggunakan uji linieritas data dengan scatter plot (diagram pancar). Berdasarkan hasil mengolah progam SPSS 16, diperoleh bahwa garis linieritas membentuk pola garis ke kanan atas, sehingga dapat disimpulkan bahwa variabel persepsi pengelompokan kelas dengan hasil belajar dan etika pergaulan peserta didik berkategori linier.

\section{HASIL DAN PEMBAHASAN}

Teknik analisis Independent T-test digunakan untuk mengetahui seberapa tinggi hasil belajar peserta didik. Hasil analisis Independent T-test disajikan pada Tabel 2.

Tabel 2. Hasil Analisis Independent T-test (Hasil Belajar)

\begin{tabular}{|c|c|c|c|}
\hline \multirow{2}{*}{ Hasil belajar } & $\mathrm{t}_{\text {hitung }}$ & Df & Sig. \\
\cline { 2 - 4 } & 24,552 & 94 & 0,000 \\
\hline
\end{tabular}

Berdasarkan analisis pada Tabel 1 dapat diketahui bahwa diperoleh nilai $t_{\text {hitung }}$ sebesar 24,552.Nilai $t_{\text {hitung dibandingkan }}$ dengan nilai $t_{\text {tabel }}$ untuk menguji hipotesis yang diajukan, dengan ketentuan apabila $t_{\text {hitung }}>$ $\mathrm{t}_{\text {tabel }}$, maka $\mathrm{H}_{0}$ diterima, sedangkan apabila $\mathrm{t}_{\text {hitung }}<\mathrm{t}_{\text {tabel }}$, maka $\mathrm{H}_{0}$ ditolak.

Nilai $t_{\text {tabel }}=0,05 ;(n-1)$, maka diperoleh $t_{\text {tabel }}$ sebesar 1,665. Berdasarkan nilai tersebut diketahui bahwa $t_{\text {hitung }}$ lebih besar dari $t_{\text {tabel }}$ (24,552>1,665), maka $\mathrm{H}_{0}$ diterima.Hal tersebut dapat disimpulkan bahwa hasil belajar kognitif mata pelajaran akidah akhlak lebih besar dari 75 atau diatas nilai KKM.

Teknik analisis Independent T-test digunakan untuk mengetahui seberapa tinggi etika pergaulan peserta didik (afektif). Hasil analisis Independent T-test disajikan pada Tabel 3. 
Alisa Widiya Lestari dan Sulasfiana Alfi Raida

PENGARUH PERSEPSI PESERTA DIDIK DALAM PENGELOMPOKAN KELAS TERHADAP .. WASIS: Jurnal Ilmiah Pendidikan. Volume 1, Nomor 1, hlm. 19-27

Tabel 3. Hasil Analisis Independent T-test (Etika Pergaulan)

\begin{tabular}{|l|c|c|c|}
\hline \multirow{2}{*}{ Etika } & $\mathrm{t}_{\text {hitung }}$ & Df & Sig. \\
\cline { 2 - 4 } & 35,051 & 94 & 0,000 \\
\hline
\end{tabular}

Berdasarkan analisis pada Tabel 2 dapat diketahui bahwa diperoleh nilai $\mathrm{t}_{\text {hitung }}$ sebesar 35,051. Nilai $t_{\text {hitung dibandingkan }}$ dengan nilai $t_{\text {tabel }}$ untuk menguji hipotesis yang diajukan, dengan ketentuan apabila $t_{\text {hitung }}>$ $\mathrm{t}_{\text {tabel }}$, maka $\mathrm{H}_{0}$ diterima, sedangkan apabila $\mathrm{t}_{\text {hitung }}<\mathrm{t}_{\text {tabel }}$, maka $\mathrm{H}_{0}$ ditolak

Nilai $\mathrm{t}_{\text {tabel }}=0,05 ;(\mathrm{n}-1)$, maka diperoleh $t_{\text {tabel }}$ sebesar 1,665. Berdasarkan nilai tersebut diketahui bahwa $t_{\text {hitung }}$ lebih besar dari $t_{\text {tabel }}$ (35,051>1,665), maka $\mathrm{H}_{0}$ diterima.Hal tersebut dapat disimpulkan bahwa etika pergaulan peserta didik (afektif) lebih besar dari 75.

Untuk mengetahui tingkat hubungan antar $\mathrm{X}$ terhadap $\mathrm{Y}_{1}$, maka dilakukan perhitungan analisis uji hipotesis. Adapun hasil analisis regresi yang diperoleh dengan bantuan progam SPSS 16 disajikan pada Tabel 4.

Tabel 4. Hasil Uji Hipotesis Asosiatif $\mathrm{X}$ terhadap $\mathrm{Y}_{1}$

\begin{tabular}{|c|c|c|c|c|c|}
\hline $\begin{array}{c}\mathrm{X} \\
\text { terhada } \\
\mathrm{p} \mathrm{Y}_{1}\end{array}$ & $\begin{array}{c}\text { Nilai } \\
\mathrm{a}\end{array}$ & $\begin{array}{c}\text { Nilai } \\
\mathrm{b}\end{array}$ & $\mathrm{R}$ & $\begin{array}{c}\mathrm{R} \\
\text { Squar } \\
\mathrm{e}\end{array}$ & Sig. \\
\cline { 2 - 6 } & $\begin{array}{c}62,22 \\
3\end{array}$ & 0,352 & 0,573 & 0,328 & 0,000 \\
\hline
\end{tabular}

Berdasarkan hasil analisis pada Tabel 3, maka diperoleh nilai signifikansi sebesar 0,000 atau lebih dari $0,05 \quad(0,000<0,05)$. Sehingga dapat disimpulkan bahwa $\mathrm{H}_{0}$ ditolak dan $\mathrm{H}_{\mathrm{a}}$ diterima. Hal tersebut menunjukkan bahwa ada pengaruh antara persepsi peserta didik dalam pengelompokan kelas terhadap hasil belajar kognitif peserta didik. Nilai koefisien determinasi $\mathrm{R}$ square diperoleh sebesar 0,328 atau $32 \%$. Hal tersebut dapat disimpulkan bahwa pengaruh antara persepsi peserta didik dalam pengelompokan kelas terhadap hasil belajar kognitif peserta didik sebesar $32 \%$.

Untuk mengetahui tingkat hubungan antar variabel $\mathrm{X}$ terhadap $\mathrm{Y}_{2}$, maka akan dilakukan perhitungan analisis uji hipotesis. Adapun hasil analisis regresi yang diperoleh dengan bantuan progam SPSS 16 disajikan pada Tabel 5.
Tabel 5. Hasil Uji Hipotesis Asosiatif $X$ terhadap $\mathrm{Y}_{2}$

\begin{tabular}{|c|c|c|c|c|c|}
\hline \multirow[t]{2}{*}{$\begin{array}{c}\mathrm{X} \\
\text { terhada } \\
\mathrm{p} \mathrm{Y}_{2}\end{array}$} & $\begin{array}{c}\text { Nilai } \\
\text { a }\end{array}$ & $\begin{array}{c}\text { Nilai } \\
\text { b }\end{array}$ & $\mathrm{R}$ & $\begin{array}{c}\mathrm{R} \\
\text { Squar } \\
\mathrm{e} \\
\end{array}$ & Sig. \\
\hline & $\begin{array}{c}24,05 \\
0\end{array}$ & 0,322 & 0,612 & 0,374 & $\begin{array}{c}0,00 \\
0\end{array}$ \\
\hline
\end{tabular}

Berdasarkan hasil analisis pada Tabel 4, maka diperoleh nilai signifikansi sebesar 0,000 atau lebih dari $0,05 \quad(0,000<0,05)$. Sehingga dapat disimpulkan bahwa $\mathrm{H}_{0}$ ditolak dan $\mathrm{H}_{\mathrm{a}}$ diterima. Hal tersebut menunjukkan bahwa ada pengaruh antara persepsi peserta didik dalam pengelompokan kelas terhadap etika pergaulan peserta didik. Nilai koefisien determinasi $\mathrm{R}$ square diperoleh sebesar 0,374 atau $37 \%$. Hal tersebut dapat disimpulkan bahwa pengaruh antara persepsi peserta didik dalam pengelompokan kelas terhadap hasil belajar kognitif peserta didik sebesar $37 \%$.

Berdasarkan hasil penelitian menunjukkan bahwa persepsi peserta didik dalam pengelompokan kelas di MTs Ma'ahid Kudus masuk kategori baik. Hal tersebut ditujukkan dengan nilai mean sebesar 78,84211 berada pada interval kategori baik (interval 87-77). Sehingga, dengan adanya persepsi yang baik maka akan berdampak pada hasil belajar yang baik pula.

Hasil belajar peserta didik kelas VIII MTs Ma'ahid Kudus juga menunjukkan kategori baik. Hal tersebut dibuktikan dengan rata-rata nilai yang diperoleh peserta didik diatas nilai KKM yang telah ditentukan, yaitu sebesar 89,95 yang masuk dalam kategori baik. Sehingga dapat dibuktikan bahwa ada pengaruh positif antara persepsi peserta didik dalam pengelompokan kelas berdasarkan jenis kelamin terhadap hasil belajar kognitif peserta didik.

Data lain menunjukkan koefisien korelasi antara persepsi peserta didik dengan hasil belajar diperoleh nilai sebesar 0,57233, hal tersebut termasuk kedalam kategori cukup. Artinya, persepsi peserta didik cukup berpengaruh dalam meningkatkan hasil belajar peserta didik. Sumbangan pengaruh persepsi peserta didik terhadap hasil belajar adalah sebesar $32,7 \%$. Selain itu hasil uji hipotesis asosiatif juga menunjukkan adanya pengaruh antara persepsi peserta didik dalam pengelompokan kelas terhadap hasil belajar. Berdasarkan peritungan diperoleh nilai signifikansi sebesar 0,000 atau lebih dari 0,05 $(0,000<0,05)$. Sehingga dapat disimpulkan bahwa $\mathrm{H}_{0}$ ditolak dan $\mathrm{H}_{\mathrm{a}}$ diterima. Hal tersebut menunjukkan bahwa ada pengaruh antara 
persepsi peserta didik dalam pengelompokan kelas terhadap hasil belajar peserta didik.

Persepsi individu dapat dipengaruhi oleh beberapa faktor. Faktor pertama yaitu interaksi yang terjadi di dalam kelas. Apabila interaksi antar peserta didik di dalam kelas berjalan dengan baik, maka akan berpengaruh terhadap kegiatan pembelajaran di kelas. Peserta didik menjadi tidak canggung di dalam kelas sehingga peserta didik bebas berekspresi, berpendapat serta lebih percaya diri di dalam kelas. Semakin tinggi rasa percaya diri peserta didik, maka akan semakin tinggi pula hasil belajar yang dimiliki. Menurut Warman (2013) peserta didik yang mempunyai rasa percaya diri yang tinggi akan kemampuan yang dimiliki, maka individu tersebut akan merasa optimis, berpikir positif, tidak mudah cemas dan tidak ragu-ragu dalam menghadapi suatu permasalahan.

Faktor kedua, yaitu sosialisasi. Sosialisasi adalah proses interaksi yang dilakukan individu sebagai makhluk sosial yang tidak dapat terlepas dari pergaulan dengan individu lain. Seorang peserta didik harus mempunyai kemampuan untuk menyesuaikan diri dengan lingkungan sehingga dapat berperan dan berfungsi dalam kelompoknya. Kemampuan bersosialisasi sangat diperlukan agar peserta didik dapat mengenali dirinya, kedudukan dan perannya terhadap teman-teman yang lain.

Kemampuan bersosialisasi dapat dilihat dari komunikasi antar teman. Komunikasi yang baik akan berpengaruh terhadap proses sosialisasi dengan teman yang lain. Selain komunikasi, kemampuan sosialisasi dapat dilihat dari kerjasama antar teman. Menurut Zuliatun (2010) kerjasama dapat berupa kerjasama dalam menyelesaikan tugas, sehingga antara peserta didik satu dengan yang lainnya dapat saling bertukar pendapat tentang tugasnya. Hal ini senada dengan riset Pratiwi, Ardianti, dan Kanzunnudin (2018) yang menemukan bahwa model project based learning $(P j B L)$ berbantuan metode edutainment dapat meningkatkan kemampuan kerjasama dan hasil belajar siswa kelas IV SD Muhammadiyah Kudus.

Sosialisasi yang baik akan bermanfaat bagi diri peserta didik, di antaranya dapat meningkatkan peranan sosial di lingkungannya, dapat menyesuaikan diri dengan lingkungan sosialnya serta terintegrasi secara kuat dengan banyak teman yang ditandai dengan keakraban dan persaudaraan. Selain itu sosialisasi juga dapat memberikan banyak teman atau relasi sehingga memperluas pergaulan serta keberhasilan dalam pembelajaran. Hal tersebut sejalan dengan pendapat Zuliatun (2010) bahwa kemampuan sosialisasi peserta didik akan memiliki pengaruh terhadap prestasi belajar peserta didik.

Faktor ketiga, yaitu hubungan pertemanan. Pertemanan merupakan hubungan dua individu yang saling berinteraksi dalam segala kondisi dan saling memberikan dukungan emosi. Hubungan pertemanan memiliki berbagai macam fungsi, diantaranya memfasilitasi proses belajar dan perkembangan individu. Tarsidi (2008) menyatakan bahwa melalui hubungan pertemanan, individu akan memperoleh kesempatan untuk belajar ketrampilan sosial yang berguna bagi kehidupannya di masa yang akan datang serta mampu memberikan individu rasa aman saling memberikan dukungan dalam mengatasi segala persoalan.

Selain sebagai sumber dukungan emosi, hubungan pertemanan memiliki fungsi sebagai sumber kognitif. Hubungan pertemanan memungkinkan individu untuk saling belajar, diantaranya melalui proses pembelajaran di kelas dengan menggunakan jenis pengajaran antar teman sebaya, yaitu cooperative learning, peer tutor dan sebagainya. Pembelajaran dengan modelmodel tersebut memungkinkan individu saling bertukar informasi dan bekerjasama untuk menyelesaikan tugas yang didapatkan (Margono, 2014).

Faktor keempat, yaitu proses pembelajaran. Pembelajaran merupakan kegiatan transfer ilmu pengetahuan yang dilakukan oleh pendidik kepada peserta didik dengan tujuan agar peserta didik mampu menguasai pengetahuan serta pembentukan sikap dan kepercayaan pada peserta didik. Komponen-komponen pokok dalam pembelajaran diantaranya tujuan pembelajaran, pendidik, peserta didik, kurikulum, strategi pembelajaran, media pembelajaran, dan evaluasi pembelajaran. Hubungan antara komponen-komponen pembelajaran tersebut membentuk suatu kegiatan yang bernama proses pembelajaran (Rahmawati, 2015).

Pada kegiatan pembelajaran memunculkan interaksi antara peserta didik dengan guru maupun peserta didik dengan peserta didik. Peserta didik mengalami perubahan tingkat perkembangan yang terbentuk melalui interaksi-interaksi tersebut. Perubahan tersebut berupa perubahan tingkat perkembangan aktual menuju tingkat 
perkembangan potensial. Tingkat perkembangan aktual merupakan tingkat perkembangan yang dicapai oleh peserta didik sebagai hasil belajar. Sedangkan tingkat perkembangan potensial merupakan hasil perkembangan yang dapat dicapai oleh peserta didik dari proses interaksi atau dapat disebut kemampuan sosial (Widyaningsih, 2015).

Menurut Jenkins dan Unwin hasil belajar tidak hanya dalam bentuk penguasaan, pengetahuan dan kecakapan dalam berbagai aspek kehidupan tetapi juga perubahan tingkah laku dalam diri peserta didik (Karwati, 2015). Hal tersebut sesuai dengan pernyataan Moh. Surya yang mengemukakan bahwa perubahan dari proses belajar bukan hanya memperoleh pengetahuan, tetapi juga perubahan dalam sikap dan keterampilan (Basri, 2015).

Sikap dan perbuatan manusia tidak terlepas dari sifat baik dan buruk, harus dilakukan dan harus ditinggalkan, hal tersebut berkaitan erat dengan masalah etika. Etika merupakan cara individu dalam menjalani hidupnya melalui tindakan-tindakan yang dilakukan dalam kehidupan sehari-hari dan membantu individu untuk mengambil sikap dan bertindak secara tepat. Untuk menentukan apakah tindakan individu termasuk tindakan baik atau buruk, maka diperlukan akal atau pikiran sebelum melakukan tindakan (Mubasyaroh, 2008). Hal tersebut berlaku dalam pergaulan sosial ketika ada orang lain yang melihat perbuatan atau tindakan yang dilakukan, seperti bersikap ramah, menyapa, mengahrgai orang lain, dan perilaku baik lainnya (Sagala, 2013).

Etika dipengaruhi oleh berbagai faktor diantaranya yaitu sifat manusia sendiri.Sifat tersebut diantaranya yaitu sifat baik dan sifat buruk. Sifat tersebut tidak bisa dipisahkan dari dalam diri manusia. Faktor kedua yaitu adanya norma-norma yang berlaku di masyarakat. Adanya aturan-atauran atau norma yang berlaku di masyarakat akan mempengaruhi seseorang dalam mengambil sikap. Norma tersebut menjadi pedoman dan pegangan seseorang dalam berperilaku (Abdullah, 2009).

Islam telah mengatur batasan-batasan dalam pergaulan dan etika, sehingga dalam perilaku perlu diperhatikan batasan-batasan tersebut dan dibiasakan sesuai dengan pedoman yang berlaku dalam kehidupan sehari-hari. Ahmad (2016) berpendapat bahwa etika pergaulan yang sesuai dengan ajaran Islam sangat penting bagi peserta didik, karena dengan adanya etika maka akan terbentuk akhlaqul karimah di dalam diri peserta didik.

Pembelajaran yang ada di madrasah yang membahas tentang etika dan sikap peserta didik terdapat dalam mata pelajaran akidah akhlak. Disampaikannya mata pelajaran ini, agar peserta didik mampu mengenal dan memahami keyakinannya kepada Allah SWT sehingga dapat direalisasikan dalam bentuk sikap yang sesuai dengan ajaran agama Islam.

Pembelajaran ini penting disampaikan kepada peserta didik sebagai pedoman dalam bersikap dan beretika dalam kehidupan seharihari. Salah satu materi pada mata pelajaran akidah akhlak yang penting disampaikan kepada peserta didik yaitu materi akhlak tercela. Materi tersebut membahas mengenai perilaku-perilaku yang wajib di hindari dalam berinteraksi dan bergaul di kehidupan seharihari di lingkungan sekolah, keluarga, maupun masyarakat.

Khususnya pada materi perilaku tercela hasad, dendam, ghibah, fitnah dan namimah. Materi tersebut dapat memberikan peserta didik pengetahuan mengenai bahaya perilaku tercela sehingga dapat dijadikan pedoman dalam beretika di kehidupan sehari-hari. Akhlak tercela wajib dihindari karena dapat menimbulkan berbagai macam kerugian, bagi diri sendiri, orang lain, maupun lingkungan sekitar. Indikator etika pergaulan peserta didik yang sesuai dengan materi perilaku tercela hasad, dendam, ghibah, fitnah dan namimah yaitu pertama, peserta didik mampu memaafkan kesalahan orang lain tanpa menyimpan dendam di hati. Hal tersebut dapat terlihat pada peserta didik yang segera meminta maaf apabila menyinggung perasaan teman.

Kedua, mampu berbicara dengan sopan sesuai fakta yang terjadi.Hal tersebut berkaitan dengan perilaku tercela ghibah dan fitnah.Hal tersebut dapat dibuktikan melalui angket yang diberikan kepada peserta didik yang memilih jawaban tidak pernah membicarakan keburukan teman. Sebagaimana telah termuat dalam al-Qur'an dan hadits tentang bahaya perilaku ghibah dan fitnah yang sangat merugikan diri sendiri maupun orang lain. Orang yang melakukan perbuatan ghibah disamakan dengan orang yang memakan bangkai saudaranya sendiri.

Ketiga, mampu bersikap baik, ramah dan menghargai orang lain. Peserta didik mampu bersikap baik dan menghindari perilaku tercela hasad dan namimah. Hal tersebut terlihat pada angket yang diberikan 
kepada peserta didik yang tidak setuju dengan perilaku mencelakakn orang lain karena merasa tersaingi. Sebab, hal tersebut sangat merugikan diri sendiri maupun orang lain. Namun, terkadang perilaku hasad yang dimiliki individu kurang disadari bahayanya bagi diri sendiri maupun orang lain dikemudian hari. Secara umum, dampak dari perilaku-perilaku tercela tersebut diantaranya dapat memutuskan rasa persaudaraan sehingga menimbulkan permusuhan.

Berdasarkan hasil penelitian, persepsi peserta didik dalam pengelompokan kelas juga berpengaruh terhadap etika pergaulan peserta didik. Hal tersebut didasarkan pada data yang menunjukkan koefisien korelasi sebesar 0,611829, hal tersebut termasuk kedalam kategori kuat. Artinya, persepsi peserta didik memiliki pengaruh yang kuat terhadap etika pergaulan peserta didik. Sumbangan pengaruh persepsi peserta didik terhadap etika pergaulan peserta didik adalah sebesar $37,3 \%$. Selain itu hasil uji hipotesis asosiatif juga menunjukkan adanya pengaruh antara persepsi peserta didik dalam pengelompokan kelas berdasarkan jenis kelamin terhadap etika pergaulan peserta didik. Berdasarkan peritungan diperoleh nilai signifikansi sebesar 0,000 atau lebih dari 0,05 $(0,000<0,05)$. Sehingga dapat disimpulkan bahwa $\mathrm{H}_{0}$ ditolak dan $\mathrm{H}_{\mathrm{a}}$ diterima.Hal tersebut menunjukkan bahwa ada pengaruh antara persepsi peserta didik dalam pengelompokan kelas terhadap etika pergaulan peserta didik.

Hal tersebut relevan dengan pendapat Rokeach, bahwa di dalam persepsi terkandung komponen kognitif dan komponen konatif, yaitu sikap untuk merespon sesuatu sebagai acuan untuk berperilaku (Wulandari, 2017). Apabila peserta didik merespon positif lingkungan disekitarnya, maka perilaku atau pergaulan peserta didik juga akan positif.

Berdasarkan hasil penelitian dan pembahasan di atas, maka dapat diperoleh hasil bahwa persepsi peserta didik dalam pengelompokan kelas berpengaruh terhadap hasil belajar peserta didik dan etika pergaulan peserta didik.Selain itu, peserta didik menyakan setuju apabila keadaan kelas tanpa adanya lawan jenis membuat peserta didik lebih fokus dalam kegiatan pembelajaran. Peserta didik menjadi lebih nyaman, percaya diri dan bebas berekspresi tanpa adanya lawan jenis di dalam kelas.

\section{SIMPULAN}

Pemaparan dari hasil analisis penelitian pengaruh persepsi peserta didik dalam pengelompokan kelas terhadap hasil belajar dan etika pergaulan peserta didik pada mata pelajaran akidah akhlak kelas VIII MTs Ma'ahid Kudus yang telah dilakukan oleh peneliti dapat disimpulkan sebagai berikut.

1. Hasil belajar kogitif mata pelajaran akidah akhlak kelas VIII MTs Ma'ahid Kudus termasuk kategori baik, yaitu berada pada interval (94-89).

2. Hasil belajar afektif (etika pergaulan) peserta didikkelas VIII MTs Ma'ahid Kudus termasuk pada kategori baik, yaitu pada interval (50-54).

3. Pengaruh antara persepsi peserta didik dalam pengelompokan kelas terhadap hasil belajar kognitif peserta didik pada mata pelajaran akidah akhlak kelas VIII di MTs Ma'ahid Kudus sebesar $32 \%$.

4. Pengaruh antara persepsi peserta didik dalam pengelompokan kelas terhadap hasil belajar afektif (etika pergaulan) peserta didik pada mata pelajaran akidah akhlak kelas VIII di MTs Ma'ahid Kudus sebesar $37 \%$.

\section{DAFTAR PUSTAKA}

Abdullah, M. Yatimin . 2009. Pengantar Studi Etika. Jakarta: PT RajaGrafindo Persada.

Afryansih, Nila. 2016. Hubungan Antara Persepsi Siswa Tentang Penilaian Guru dan Motivasi Belajar dengan Hasil Belajar Geografi SMAN 15 Padang. Jurnal Curricula, 1 (3).

Ahmad, M. Yusuf, dkk. 2016. Etika Pergaulan Islami Santri Madrasah Aliyah (MA) di Pesantren Jabal Nur Kecamatan Kandis Kabupaten Siak. Jurnal Al-Hikmah, 13 (2).

Arifin, Zaki Zaenal. 2018. Pengaruh Prsepsi Siswa Atas Lingkungan Belajar dan Kecerdasan Intelektual Terhadap Kemampuan Berbicara Bahasa Inggris. Jurnal Sekretari, 5(2).

Azra, Azyumardi. 2014. Pendidikan Islam: Tradisi dan Moderisasi Ditengah Tantangan Milenium III. Jakarta: Kencana Prenada Media.

Basri, Hasan. 2013. Landasan Pendidikan. Bandung: CV Pustaka Setia. 
Basri, Hasan. 2015. Paradigma Baru Sistem Pembelajaran. Bandung: CV Pustaka Setia.

Hamdani. 2011. Dasar-Dasar Kependidikan. Bandung: CV Pustaka Setia.

Hardjana, Agus M. 2003. Komunikasi Intrapersonal \& Interpersonal. Yogyakarta: Kanisius.

Harianto, Sugeng. 2018. "Kenakalan Remaja di Nganjuk Meningkat 50\%, Polisi Blusukan Ke Sekolah”, (Detiknews).

Karwati, Euis dan Donni Juni Priansa. 2015. Manajemen Kelas. Bandung: ALFABETA.

Kompri. 2014. Manajemen Sekolah: Teori dan Praktik. Bandung :ALFABETA.

Mahmud. 2012. Psikologi Pendidikan. Bandung: CV Pustaka Setia.

Margono, Ami Dwi .2014. Hubungan Harga Diri dan Dukungan Teman Sebaya dengan Prestasi Belajar, Thesis UIN Sunan Ampel Surabaya.

Mubasyaroh.2008. Materi Pembelajaran Aqidah Akhlak. Kudus: DIPA STAIN Kudus.

Muchith, Saekhan. 2008. Pembelajaran Kontekstual. Semarang: RaSAIL Media Group.

Ningrum, Diah. 2015. "Kemerosotan Moral Di Kalangan Remaja: Sebuah Penelitian Mengenai Parenting Style dan Pengajaran Adab”, UNISIA, 37(2).

Pawitasari, Erma. 2015. "Pendidikan Khusus Perempuan: Antara Kesetaraan Gender dan Islam”, Jurnal Pendidikan, 11(2).

Rahmawati, Tutik, Daryanto. 2015. Teori Belajar dan Proses Pembelajaran Yang Mendidik. Yogyakarta: Gava Media.
Sagala, Syaiful. 2013. Etika dan Moralitas Pendidikan Peluang dan Tantangan, (Jakarta: Prenamedia Group.

Sriyono, Heru. 2017. "Persepsi Siswa Mengenai Lingkungan dan Kebiasaan Belajar Terhadap Prestasi Belajar Siswa Pada Mata Pelajaran Ilmu Pengetahuan Sosial", SOSIO-E-KONS, 9(1).

Tarsidi, Didi. 2008. "Peranan Hubungan Teman Sebaya dalam Perkembangan Kompetensi Sosial Anak".

Wantu, Tuti, Amrin M. Ade. 2017. "Pengaruh Bimbingan Klasikal Teknik Cinema Therapy Terhadap Etika Pergaulan Pada Siswa Kelas XI SMK Negeri 2 Kota Gorontalo", Jurnal Ilmiah dalam Implementasi Kurikulum Bimbingan Konseling Berbasis KKNI .

Warman, Dewi. 2013 "Hubungan Percaya Diri Siswa dengan Hasil Belajar Geografi Kelas XI IPS di SMAN 1 Bayang Kabupaten Pesisir Selatan”.

Widyaningsih, Sundari, Irsad Rosidi. 2015. "Pengaruh Pembelajaran Aktif Terhadap Hasil Belajar Siswa Pada Materi Pokok Plantae, Jurnal Pena Sains, 2(2).

Wulandari, dkk, Ayu. 2017. "Pengaruh Persepsi Orang Tua Tentang Pendidikan Formal Dan Lingkungan Tempat Tinggal Terhadap Pekerja Anak”, Jurnal Kultur Demokrasi.

Yusuf, Bistari Basuni. 2017. "Konsep dan Indikator Pembelajaran Efektif", Jurnal Kajian Pembelajaran dan Keilmuan, 1(2).

Zuliatun, Nur Arifah .2010. Pengaruh Kemmapuan Sosialisasi Siswa dan Keaktifan Siswa Terhadap Prestasi Belajar Siswa Pada Mata Pelajaran IPS Siswa Kelas VIII SMP Muhammadiyah 5 Surakarta. 